\title{
Pengaruh Penempatan Pegawai Terhadap Prestasi Kerja Pegawai Pada Kantor Media Lintas Indonesia Kota Palembang
}

\author{
Benny Usman \\ Manajemen, Fakultas Ekonomi Universitas PGRI Palembang \\ benny usman@univpgri-palembang.ac.id
}

\begin{abstract}
ABSTRAK
Secara teoritis terdapat faktor yang mempengaruhi prestasi kerja pegawai termasuk kesesuaian penempatan pegawai. Dalam penelitian ini yang menjadi populasi adalah seluruh pegawai pada Kantor Media Lintas Indonesia Kota Palembang yang berjumlah 32 orang dan sekaligus sebagai sampel penelitian. Metode pengumpulan data menggunakan kuisioner. Teknik analisis data yang digunakan adalah regresi linier sederhana dengan bantuan software SPSS 22.0 for windows. Hasil penelitian menunjukkan bahwa secara parsial variable penempatan pegawai berpengaruh signifikan terhadap prestasi kerja pegawai pada Kantor Media Lintas Indonesia Kota Palembang. Hal ini bisa dilihat dari hasil uji hipotesis diperoleh nilai signifikan semuanya lebih kecil dibandingkan dengan alpha pada taraf nyata 0,05 .
\end{abstract}

Kata kunci: Penempatan Pegawai dan Prestasi Kerja

\section{A. PENDAHULUAN}

Negara Indonesia adalah Negara yang sedang berkembang. Didalam menghadapi era globalisasi pada saat ini, suatu organisasi baik pemerintah maupun swasta harus siap bersaing dan menerima tantangan demi kemajuan. Tantangan tersebut berasal dari dalam organisasi maupun kemajuan. Tantangan tersebut berasal dari dalam organisasi maupun dari luar organisasi yang bersangkutan. Oleh karena itu suatu organisasi harus dapat menyikapi dan menanggulangi kemungkinan-kemungkinan yang telah ataupun akan terjadi, agar organisasi tersebut akan lebih baik kehidupannya dimasa yang akan datang.

Dalam menyikapi kemungkinan tersebut ada suatu aspek yang perlu diperhatikan yaitu kesesuaian penempatan kerja pegawai dengan latar belakang pendidikan dan jabatan masing-masing. Apabila penempatan pegawai tersebut sudah sesuai dengan porsinya maka akan berdampak terhadap prestasi kerja pegawai tersebut.

Penempatan pegawai yang sesuai, tentu akan berpengaruh juga terhadap keberhasilan organisasi secara keseluruhan. Penempatan ini harus berdasarkan job description dan specification yang telah ditentukan serta berpedoman kepada prinsipprinsip penempatan orang yang tepat untuk jabatan yang tepat. ( The right man in the right place and the right man behind the right job). Sebelum organisasi menempatkan pegawai pada posisi tertentu langkah pertama yang harus diambil yaitu membuat analisa jabatan. Masalah penempatan ini erat hubungannya dengan seleksi penerimaan pegawai karena pegawai yang ada merupakan asset utama bagi organisasi tersebut.

Penempatan pegawai setelah adanya proses seleksi dilakukan apabila pegawai yang ada tidak tersedia atau 
kekurangan pegawai pada posisi tertentu, maka penempatan pegawai akan diambil melalui proses seleksi untuk mengisi posisi tersebut. Selain penempatan pegawai yang berasal dari penarikan (recruitment) dari luar instansi, penempatan pegawai juga bisa berasal dari dalam instansi sendiri atau dikenal dengan istilah alih tugas yaitu penempatan pegawai pada tugas baru dengan tanggung jawab yang relatif sama dengan statusnya yang lama. Dengan demikian pegawai ditempatkan pada satuan kerja baru yang lain dari satuan kerja dimana seseorang pegawai selama ini bekerja.

Tujuan penempatan pegawai ini adalah untuk menempatkan orang yang tepat pada jabatan yang sesuai dengan minat dan kemampuan pegawai, sehingga sumber daya manusia yang ada menjadi produktif. Penempatan yang tepat merupakan suatu cara yang bukan hanya untuk mengoptimalkan kemampuan dan keterampilan menuju prestasi kerja yang tinggi bagi pegawai itu sendiri, akan tetapi juga merupakan bagian dari sebuah proses pengembangan pegawai di masa depan.

Begitu pula yang terjadi pada Kantor Media Lintas Indonesia Kota Palembang, suatu organisasi yang juga harus memperhatikan kedudukan dan jabatan yang ditempati oleh pegawai di Kantor Media Lintas Indonesia Kota Palembang, agar tujuan organisasi dapat dicapai dengan baik. Tetapi didalam kenyataan ada pegawai yang tidak ditempatkan pada tempatnya sesuai dengan pendidikannya.

Baik buruknya prestasi kerja seorang pegawai tentunya dapat dikaitkan dengan kesesuaian penempatan kerja mereka pada bidang pekerjaan yang sudah ditentukan. Hal ini disebabkan kesesuaian penempatan kerja tidak hanya dapat dilihat sebagai kecocokan seorang pegawai untuk mengerjakan pekerjaan tertentu, akan tetapi lebih penting lagi kesesuaian penempatan kerja merupakan syarat utama bagi terciptanya kondisi yang kondusif bagi pegawai untuk mengeluarkan segala kemampuannya dalam menyelesaikan tugas yang dibebankan. Kesesuaian penempatan kerja yang dimaksudkan dalam penelitian ini adalah kesesuaian pengetahuan, keterampilan dan kesesuaian sikap.

\section{B. KAJIAN TEORI}

1) Pengertian Penempatan Pegawai Menurut Hanggraeni (2012) Penempatan pegawai atau placement adalah proses penugasan atau kembali pekerja untuk mengerjakan suatu pekerjaan atau menempati suatu posisi baru di dalam perusahaan. Penempatan bertujuan untuk menempatkan seorang karyawan pada suatu posisi atau jabatan tertentu yang dianggap pas untuk dirinya. Penempatan kinerja yang tepat pada posisi yang tepat bukan saja menjadi idaman perusahaan, tetapi juga menjadi keinginan para karyawan yang bersangkutan agar dapat mengetahui ruang lingkup pekerjaan yang dibebankan kepadanya.

Menurut Rivai (2010) penempatan adalah penugasan atau penugasan kembali seseorang pegawai pada pekerjaan barunya. Penempatan pegawai berarti mengalokasikan para pegawai pada posisi kerja tertentu, hal ini khusus terjadi pada pegawai baru. Kepada para pegawai lama yang telah menduduki jabatan atau pekerjaan termasuk sasaran fungsi penempatan pegawai dalam arti mempertahankan pada posisinya atau memindahkan pada posisi lain. 
Proses penempatan dan seleksi merupakan salah satu fungsi terpenting dalam manajemen sumber daya manusia, karena tersedia atau tidaknya pekerja dalam jumlah dan kualitas yang sesuai dengan kebutuhan organisasi, diterima atau tidaknya pelamar yang telah lulus rekrutmen, tepat atau tidaknya penempatan seorang pekerja pada posisi tertentu, sangat ditentukan oleh fungsi seleksi dan penempatan.

Menurut Rivai (2010) menyatakan bahwa sering terjadi penempatan internal tanpa orientasi, karena pegawai lama dianggap telah mengetahui segala sesuatu tentang instansi. Pegawai berpengalaman memang sudah mengetahui instansi dengan baik, tetapi ia tidak mengetahui hal-hal yang berkaitan dengan pekerjaan dan lingkungan kerjanya yang baru.

Menurut

Hasibuan

(2013)

menyatakan penempatan (placement) pegawai adalah tindak lanjut dari seleksi yaitu menempatkan calon pegawai yang diterima (lulus seleksi) pada jabatan atau pekerjaan yang membutuhkannya sekaligus mendelegasikan authority kepada orang tersebut, dengan demikian calon pegawai itu akan dapat mengerjakan tugas-tugasnya di jabatan bersangkutan.

Menurut Handoko

(2010) penempatan pegawai adalah penugasan pada tugas baru dengan tanggung jawab yang relatif sama dengan status yang lama.

Menurut Rivai (2010) dalam hal keputusan penempatan pegawai biasanya lebih banyak dibuat oleh manajer lini, biasanya supervisor seorang pegawai berkonsultasi menentukan penempatan pegawai di masa datang. Terdapat tiga jenis penting dari penempatan, yaitu promosi, transfer dan demosi.

\section{Promosi}

Promosi terjadi apabila seorang pegawai dipindahkan dari satu pekerjaan ke pekerjaan lain yang lebih tinggi pembayaran, tanggung jawab dan atau level. Umumnya diberikan sebagai penghargaan, hadiah (reward system) atas usaha dan prestasinya di masa lampau.

2. Transfer dan Demosi

Transfer dan demosi adalah dua kegiatan utama penempatan pegawai lainnya yang ada pada suatu instansi. Transfer terjadi kalau seorang pegawai dipindahkan dari satu bidang tugas ke bidang lainnya yang tingkatannya hampir sama baik tingkat gaji, baik tingkat gaji, tanggung jawab maupun tingkat strukturalnya.

Demosi jarang menimbulkan hasil positif bagi seorang pegawai. Biasanya hal tersebut terjadi karena masalah kedisiplinan, pegawai didemosi karena kinerja yang tidak baik, atau karena ketidaktaatan terhadap disiplin kerja seperti terlalu sering absen atau tidak hadir. Satu permasalahan akan timbul akibat demosi, yaitu pegawai mungkin akan kehilangan motivasi kerja atau yang lebih jelek dari itu yang akhirnya dapat menimbulkan keraguan yang lebih besar yang disebabkan oleh keputusan demosi. Disamping menimbulkan pengaruh negatif bagi moral pegawai yang lain, pegawai yang didemosi juga akan makin tidak produktif, dan makin jelek loyalitasnya.

$$
\text { Menurut Siagian }
$$

Penempatan yang tepat adalah kinerja seseorang dan produktivitas kerjanya ditentukan oleh tiga faktor utama berikut ini:

1. Motivasinya.

Yang dimaksud dengan motivasi ialah daya dorong yang dimiliki, baik 
secara instrinsik maupun secara ekstrinsik, yang membuatnya mau dan rela untuk bekerja sekuat tenaga dengan mengerahkan segala kemampuan yang ada demi keberhasilan organisasi dalam mencapai tujuan dan berbagai sasarannya.

2. Kemampuan.

Ada kemampuan yang bersifat fisik dan ini lebih diperlukan oleh pegawai yang dalam pelaksanaan tugasnya lebih banyak mmenggunakan otot. Di lain pihak, ada kemampuan yang bersifat mental, yang lebih banyak dituntut oleh penyelesaian tugas pekerjaan dengan mnggunakan otak.

3. Ketepatan Penugasan.

Dalam dunia manajemen ada ungkapan mengataan bahwa, Tidak ada pegawai yang bodoh, yang bodoh adalah para manajer yang tidak mengenali secara tepat pengetahuan, keterampilan, kemampuan, bakat dan minat para bawahannya. Memang telah terbukti, bahwa dengan penempata yang tidak tepat, kinerja seseorang tidak sesuai dengan harapan manajemen dan tuntutan organisasi, dengan demikian, mereka menampilkan produktivitas kerja yang rendah.

\section{2) Faktor-faktor Pertimbangan Dalam Penempatan}

Dalam penempatan pegawai, perlu dipertimbangan faktor-faktor yang mungkin sangat berpengaruh terhadap kontinuitas perusahaan. Adapun faktor-faktor yang harus dipertimbangkan dalam penempatan pegawai sebagai berikut :

1. Faktor prestasi akademis

Pegawai yang mempunyai prestasi akademis yang tinggi harus ditempatkan pada tugas dan pekerjaan yang diperkirakan dia mampu mengembannya. Walaupun tugas dan pekerjaan tersebut dipandang berat, yakni memerlukan wewenang dan tanggung jawab yang besar.

Sebaliknya bagi karyawan yang mempunyai latar belakang pendidikan akademis yang pas dibawah standar ditempatkan pada tugas dan pekerjaan yang ringan pula, yaitu tugas dan pekerjaan yang hanya mempunyai wewenang dan tanggung jawab yang relative rendah.

2. Faktor pengalaman

Pegawai yang mempunyai pengalaman bekerja cenderung memiliki keahlian dan keterampilan kerja yang relative tinggi. Demikian sebaliknya, jika tidak memiliki pengalaman kerja cenderung tidak memiliki keahlian dan keterampilan.

3. Faktor kesehatan fisik dan mental Kesehatan fisik dan mental perlu mendapat pertimbangan dalam menempatkan karyawan karena tanpa pertimbangan, hal-hal yang bakal merugikan perusahaan tidak mustahil akan terjadi. Kondisi fisik pegawai yang bersangkutan untuk pertimbangan pada tempat dimana pegawai tersebut untuk diberikan tugas dan pekerjaan yang cocok baginya berdasarkan kondisi fisik dan mentalnya rendah atau lemah sebaiknya ditempatkan pada bagian-bagian yang tidak begitu memerlukan karyawan yang kuat, begitu pula sebaliknya.

4. Faktor status perkawinan

Status perkawinan sangat perlu untuk dipertimbangkan dalam penempatan karyawan yang bersangkutan. Pegawai wanita yang mempunyai suami perlu 
mendapat pertimbangan apalagi kalau sudah mempunyai anak. Sebaliknya karyawan yang bersangkutan ditempatkan pada pekerjaan yang tidak begitu mempunyai resiko, cukup diberikan pekerjaan yang seimbang dengan kondisi fisiknya.

\section{3) Prestasi Kerja \\ $>$ Pengertian Prestasi Kerja}

Menurut Sutrisno (2012) Prestasi kerja adalah sebagai hasil kerja yang telah dicapai seseorang dari tingkah laku kerjanya dalam melaksanakan aktivitas kerja.

Menurut Hasibuan (2013) Prestasi kerja adalah suatu hasil kerja yang dicapai seseorang dalam melaksanakan tugas-tugas yang dibebankan kepadanya yang didasarkan atas kecakapan, pengalaman, dan kesungguhan serta waktu.

Menurut Bernardin dan Russel dalam Sutrisno (2012) memberikan definisi tentang Prestasi kerja adalah catatan tentang hasil-hasil yang diperoleh Dari fungsi-fungsi pekerjaan tertentu atau kegiatan tertentu selama kurun waktu tertentu.

\section{$>\quad$ Penilaian Prestasi Kerja}

Menurut Sutrisno (2012) pengertian penilaian prestasi karyawan adalah kegiatan manajemen untuk mengevaluasi perilaku prestasi kerja karyawan serta menetapan kebijakan selanjutnya.

Penilaian perilaku meliputi penilain kesetiaan, kejujuran, dedikasi dan partisifasi karyawan. Menilai perilaku ini sulit karena tidak ada standart fisiknya, sedangkan untuk penilaian hasil kerja relatif lebih mudah karena ada standar fisik yang dapat dipakai sebagai tolok ukurnya, separti meter, liter, kilogaram.

Menurut Handoko (2010) Penilaian prestasi kerja (performance appraisal) juga dapat diartikan sebagai proses melalui mana organisasi-organisasi menevaluasi atau menilai prestadi kerja pegawai, kegiatan ini dapat memperbaiki keputusan-keputusan personalia dan memberikan umpan baik kepada para pegawai tentang pelaksanaan kerja mereka.

Menurut Siagian (2013) dalam hubungannya dengan pelaksanaan penilaian prestasi kerja pegawai, menyatakan dasar yang dipakai dalam menentukan pelaksanaan penilaian prestasi kerja terdiri dari:

a) Faktor kejelasan: berkaitan dengan kejelasan peaksanaan, tujuan penilaian, prosedur penilaian, siapa yang menlai dan kriteria yang dinilai.

b) Faktor motivasi: berkaitan dengan kriteria penilaian, dampak penilaian terhadap promosi, kenaikan gaji bonus, dan penghargaan

c) Faktor keadilan: berkaitan dengan objektivitas dan keadilan dalam melaksanakan penilaian.

d) Faktor feedback: berkaitan dengan umpan balik yaitu hasil penilaian dan wawancara evaluasi.

e) Faktor tindak lanjut: berkaitan dengan langkah-langkah pembinaan untuk meningkatkan dan memperbaiki prestasi kerja pegawai.

\section{Kriteria dan Jenis Informasi yang Digunakan Dalam Menilai Prestasi Kerja Pegawai \\ Menurut Sedarmayanti (2011)} menyatakan terdapat tiga jenis kriteria prestasi kerja, sebagai berikut : 
a) Kriteria berdasarkan sifat memusatkan pada karakteristik pribadi karyawan. Loyalitas, keandalan, kemampuan berkomunkasi dan keterampilan memimpin merupakan sifat yang sering dinilai selama proses penilaian. Jenis kriteria ini memusatkan diri pada bagaimana seseorang, bukan apa yang dicapai atau tidak dicapai seseorang dalam pekerjaannya.

b) Kriteria berdasarkan perilaku terfokus pada bagaimana pekerjaan dilaksanakan. kriteria ini penting bagi pekerjaan yang membutuhkan hubungan antar pribadi.

c) Kriteria berdasarkan hasil. Dengan semakin ditekankannya produktivitas dan daya saing internasional, kriteria berdasarkan hasil semakin populer. Kriteria ini terfokus pada apa yang telah dicapai atau dihasilkan daripada bagaimana sesuatu dicapai atau dihasilkan. Kriteria berdasarkan hasil, mungkin tepat jika organisasi tidak peduli bagaimana hasil dicapai, tetapi tidak tepat untuk setiap pekerjaan. Kriteria ini sering dikritik karena sering meninggalkan aspek kritis pekerjaan yang penting, seperti kualitas yang mungkin sulit dikualifikasikan.

\section{$>\quad$ Indikator-indikator Prestasi kerja}

Menurut Sutrisno (2012) ada 6 indikator-indikator yang merupakan bidang prestasi kunci bagi instansi atau perusahaan yang bersangkutan :
a. Hasil kerja
Tingkat kuantitas maupun kualitas yang telah dihasilkan dan sejauh mana pengawasan dilakukan.
b. Pengetahuan Pekerjaan

Tingkat pengetahuan yang terkait dengan tugas pekerjaan yang akan berpengaruh langsung terhadap kuantitas dan kualitas dari hasil kerja

c. Inisatif

Tingkat inisiatif selama melaksanakan tugas pekerjaan khususnya dalam hal penanganan masalah-masalah yang timbul

d. Kecekatan Mental

Tingkat kemampuan dan kecepatan dalam menerina instruksi kerja dan menyesuaikan dengan cara kerja serta situasi kerja yang ada

e. Sikap

Tingkat semangat kerja serta sikap positif dalam melaksanakan tugas pekerjaan

f. Disiplin waktu dan absensi

Tingkat ketepatan waktu dan tingkat kehadiran.

\section{Faktor-faktor mempengaruhi prestasi kerja \\ Menurut Byar dan Rue dalam} Sutrisno (2012) mengemukan adanya 2 faktor yang mempengaruhi prestasi kerja yaitu faktor individu dan faktor lingkungan.

Faktor individu yang dimaksud adalah

a. Usaha yang menunjukkan sejumlah sinergi fisik dan mental yang digunakan dalam menyelenggarakan gerakan tugas

b. Abilities, yaitu sifat-sifat personal yang diperlukan untuk melaksanakan suatu tugas

\section{METODE PENELITIAN}

Menurut Duwi Priyatno (2013) metode kuantitatif yaitu deskriftif gambaran, atau lukisan mengenai sifatsifat dari objek penelitian yang di nyatakan dalam bentuk angka untuk 
memperjelas data menggunakan SPSS Versi 22.0.

\section{POPULASI DAN SAMPEL \\ 1) Populasi}

Menurut Sugiyono (2013) populasi adalah wilayah ginerasi yang terdiri atas objek atau subjek yang mempuyai kualitas dan karakteristik tertentu yang ditetapkan oleh peneliti untuk dipelajari dan kemudian ditarik kesimpulannya.

Populasi diartikan sebagai wilayah generalisasi yang terdiri atas objek/subjek yang mempuyai karakteristik tertentu yang di tetapkan oleh peneliti untuk di pelajari dan kemudian ditarik kesimpulannya. Adapun populasi dalam penelitian ini adalah seluruh pegawai pada Kantor Media Lintas Indonesia Kota Palembang yang berjumlah 32 orang.

\section{2) Sampel}

Menurut Sugiyono (2013) metode kuantitatif yaitu deskriftif gambaran, atau lukisan mengenai sifat-sifat dari objek penelitian yang di nyatakan dalam bentuk angka untuk memperjelas data menggunakan SPSS Versi 22.0. Sampel yang diambil pada Kantor Media Lintas Indonesia Kota Palembang yang berjumlah 32 orang, menggunakan teknik sampling non probability sampling yaitu sampling jenuh.

\section{E. TEKNIK PENGUMPULAN DATA}

Menurut Sugiono (2013) ada beberapa teknik pengumpulan data yang dilakukan dalam penelitian ini adalah :
1. Kuesioner

Kuesioner adalah metode pengumpulan data yang dilakukan dengan cara memberikan pertanyaan-pertanyaan kepada responden. Responden dalam penelitian ini adalah pegawai Kantor Media Lintas Indonesia Kota Palembang.

2. Dokumentasi

Metode Dokumentasi yaitu mencari data mengenai hal-hal atau variabel yang berupa catatan, transkip, buku, surat kabar, majalah, prasasti, notulen, rapat, lengger, agenda, dan sebagainya. Metode dokumentasi digunakan untuk mengetahui struktur organisasi, tugas, dan kewajiban pegawai pegawai Kantor Media Lintas Indonesia Kota Palembang.

\section{F. TEKNIK ANALISIS DATA}

Menurut Duwi Priyatno

Teknik Analisis Data yang di gunakan dalam penelitian ini adalah analisis kuantitatif, yaitu suatu metode analisis yang menggunakan perhitungan angkaangka untuk pengambilan keputusan, selanjutnya di olah menggunakan program SPSS versi 22.0 for windows.

\section{1) Regresi Linier Sederhana}

Sugiyono (2013:218) menjelaskan analisis Regresi Linier sederhana digunakan untuk mengetahui seberapa besar pengaruh variabel bebas Penempatan Pegawai (X) terhadap variabel terikatnya yaitu Prestasi Kerja (Y).

Persamaan linier sederhana sebagai berikut :

$Y^{\prime}=a+b X$ 
Dimana :

$\mathrm{Y}^{\prime} \quad=$ subjek variabel terikat yang $\mathrm{di}$ proyeksikan

$\mathrm{X} \quad=$ variabel bebas yang mempuyai nilai tertentu untuk di prediksikan.

$$
\begin{array}{ll}
\mathrm{a} & =\text { konstanta harga } \mathrm{Y} \text { jika } \mathrm{X}=0 \\
\mathrm{~b} & =\text { koofisien korelasi }
\end{array}
$$

Untuk mencari nilai a dan b digunakan rumus sebagai berikut :

$$
b=\frac{n \cdot \sum x y-\sum x \cdot \sum y}{n \cdot \sum x^{2}-\left(\sum x\right)^{2}}
$$

\section{2) Koefisien Korelasi}

Menurut Ridwan (2009), Korelasi merupakan suatu teknik statistik yang di pergunakan untuk mengukur kekuatan hubungan 2 variabel dan juga untuk dapat mengetahui bentuk hubungan antara 2 variabel tersebut dengan hasil yang sifatnya kuantitatif.

Korelasi dapat di rumuskan :

$$
r=\frac{n \sum x y-\sum x \sum y}{\sqrt{\left[n \sum x^{2}-\left(\sum x\right)^{2} \mid n \sum y^{2}-\left(\sum y\right)^{2}\right]}}
$$

keterangan :

$\mathrm{n}=$ banyaknya pasangan data $\mathrm{x}$ dan $\mathrm{y}$

$\sum x=$ total jumlah dari variabel $x$

$\sum y=$ total jumlah dari variabel $y$

$\sum x^{2}=$ kuadrat dari total jumlah variabel $x$

$\sum \mathrm{y}^{2}=$ kuadrat dari total jumlah variabel $\mathrm{y}$

$\sum x y=$ hasil perkalian dari total jumlah variabel $x$ dan $y$

Koefisien korelasi dapat berpedoman pada ketentuan yang di perlihatkan pada tabel di bawah ini :

\section{Tabel 2}

Interpretasi Koefisien Korelasi

\begin{tabular}{|c|c|}
\hline Inter Koefisien & Tingkat Hubungan \\
\hline $0,00-0,199$ & Sangat rendah \\
\hline $0,20-0,399$ & Rendah \\
\hline $0,40-0,599$ & Sedang \\
\hline $0,60-0,799$ & Kuat \\
\hline $0,80-1,000$ & Sangat kuat \\
\hline
\end{tabular}

Sumber: Sugiyono (2013)

\section{3) Koefisien Determinasi}

Diartikan sebagai seberapa besar kemampuan semua variabel bebas dalam menjelaskan varians dari variabel terikatnya. Koefisien determinasi dihitung dengan mengkuadratkan koefisien korelasi $(R)$.

Jika nilai $(R)$ sebesar $=0,80$ maka koefisien determinasinya ( $R$ squer) sebesar $=0,80 \times 0,80=0,64$. Bearti variabel dalam menjelaskan varians dari variabel terikatnya adlah sebesar 64,0 $\%$. Bearti terdapat 36\% (100\% - 64\%)

\section{4) Uji Hipotesis \\ $>$ Uji T-test}

Menurut Sugiono (2013) Uji t dilakukan untuk menguji signifikan antara dua variabel. $t$ mengikuti fungsi $t$ dengan derajat kebebasan (n-2).

Rumus yang digunakan sebagai berikut:

$$
\text { thitung }=\frac{\sqrt{ } \mathrm{n}-2}{\sqrt{1} 1-\mathrm{r}^{2}}
$$

Keterangan :

$$
\begin{array}{ll}
\mathrm{t} & : \mathrm{t} \text { - hitung } \\
\mathrm{r} & : \text { Koefisien korelasi } \\
\mathrm{n} & : \text { Sampel }
\end{array}
$$

Kreteria Pengujian :

Ha diterima jika $P$-value $>5 \%$ atau $\mathrm{t}_{\text {hit }}<\mathrm{t}_{\text {tab }}$ Ho ditolak jika $P$-value $<5 \%$ atau thit $>$ tab Kesimpulan :

- Apabila nilai $P$-value $>5 \%$, maka $\mathrm{Ho}$ diterima dan $\mathrm{Ha}$ ditolak, artinya bahwa tidak ada pengaruh yang signifikan Penempatan Pegawai terhadap Prestasi Kerja pegawai pada Kantor Media Lintas Indonesia Kota Palembang.

- Apabila nilai $P$-value $>5 \%$, maka Ho ditolak dan $\mathrm{Ha}$ diterima, artinya bahwa ada pengaruh yang signifikan Penempatan Pegawai terhadap 
Prestasi Kerja pada Kantor Media Lintas Indonesia Kota Palembang.

\section{G. HASIL PENELITIAN}

\section{a) Analisis Regresi Linier Sederhana}

Analisis regresi linier sederhana digunakan dalam penelitian ini dengan tujuan untuk membuktikan hipotesis mengenai pengaruh variabel
Penempatan Pegawai terhadap Prestasi Kerja pada pegawai Kantor Media Lintas Indonesia Kota Palembang. Perhitungan analisis regresi linier sederhana yang digunakan dalam penelitian ini adalah dengan menggunakan bantuan program SPSS For Windows Version 22 yang hasilnya dapat dilihat pada tabel berikut:

Tabel 3

Hasil Regresi Linier Sederhana

Coefficients $^{a}$

\begin{tabular}{|c|c|c|c|c|c|}
\hline \multirow[b]{2}{*}{ Variable } & \multicolumn{2}{|c|}{$\begin{array}{c}\text { Unstandardized } \\
\text { Coefficients }\end{array}$} & $\begin{array}{l}\text { Standardized } \\
\text { Coefficients }\end{array}$ & & \\
\hline & $B$ & Std. Error & Beta & $\mathrm{t}$ & Sig. \\
\hline (Constant) & 13,242 & 7,433 & & 1,782 &, 085 \\
\hline $\begin{array}{l}\text { Penempatan } \\
\text { X }\end{array}$ & ,696 & 174 &, 590 & 4,006 &, 019 \\
\hline
\end{tabular}

a. Dependent Variable: Prestasi kerja_Y

Sumber :Output SPSS for Windows 22, 2015

Dari hasil perhitungan dengan SPSS For Windows Version 22 diperoleh persamaan regresi :

$$
\begin{aligned}
& Y^{\prime}=a+b X \\
& Y^{\prime}=13,242+0,696 X
\end{aligned}
$$

Konstanta sebesar 13,242 artinya jika Penempatan pegawai $(X)$ nilainya adalah 0 , maka Prestasi kerja $(\mathrm{Y})$ nilainya sebesar 13,242Sedangkan koefisien regresi variabel Penempatan pegawai $(X)$ sebesar 0,696 artinya jika Penempatan pegawai mengalami kenaikan sebesar 1, maka Prestasi kerja
(Y) akan mengalami peningkatan sebesar 0,696. Koefisien bernilai positif artinya ada pengaruh positif antara Penempatan pegawai dengan Prestasi kerja, semakin baik penempatan pegawai yang dilakukan maka akan meningkatkan pula prestasi kerja pegawai di Kantor Media Lintas Indonesia Kota Palembang.

\section{b) Uji Koefisien Korelasi}

Hasil analisis koefisien korelasi dengan bantuan SPSS For Windows Version 22.

Tabel 4

\begin{tabular}{|c|r|r|r|}
\hline$R$ & R Square & $\begin{array}{c}\text { Adjusted } R \\
\text { Square }\end{array}$ & $\begin{array}{c}\text { Std. Error of the } \\
\text { Estimate }\end{array}$ \\
\hline, $590^{\mathrm{a}}$ &, 349 &, 327 & 2,435 \\
\hline
\end{tabular}

Sumber : Output SPSS for Windows 22, 2015 
Dari tabel diatas, dapat dilihat bahwa korelasi $\mathrm{R}$ antara Penempatan pegawai $(\mathrm{X})$ terhadap Prestasi kerja $(\mathrm{Y})$ sebesar 0,590. Hal tersebut berarti bahwa hubungan Penempatan Pegawai (X) dengan Prestasi Kerja (Y) pada pegawai di Kantor Media Lintas
Indonesia Kota Palembang adalah sedang.

c) Koefisien Deteriminasi $\left(r^{2}\right)$

Hasil analisis koefisien disteriminasi dengan bantuan SPSS For Windows Vers 22.

Tabel 5

\begin{tabular}{|r|r|r|r|}
\hline$R$ & R Square & \multicolumn{1}{|c|}{$\begin{array}{c}\text { Adjusted R } \\
\text { Square }\end{array}$} & $\begin{array}{c}\text { Std. Error of the } \\
\text { Estimate }\end{array}$ \\
\hline, $590^{\mathrm{a}}$ &, 349 &, 327 & 2,435 \\
\hline
\end{tabular}

Sumber : Output SPSS for Windows 22, 2015

Kajian dimana $\mathrm{R}$ Square $=0,349$ atau 34,9\%. Artinya Variabel Prestasi kerja dipengaruhi oleh variabel Penempatan pegawai sebesar 34,9\% pada pegawai di Kantor Media Lintas Indonesia Kota Palembang dan sisanya
$65,1 \%$ dipengaruhi oleh faktor-faktor lain yang tidak diteliti dalam penelitian ini.

\section{d) Uji Hipotesis (uji $t$ ) \\ Tabel berikut menyajikan hasil uji \\ t yang merupakan pengujian hipotesis dalam penelitian ini.}

Tabel 6

Coefficients $^{a}$

\begin{tabular}{|c|c|c|c|c|c|}
\hline \multirow[b]{2}{*}{ Variable } & \multicolumn{2}{|c|}{$\begin{array}{l}\text { Unstandardized } \\
\text { Coefficients }\end{array}$} & \multirow{2}{*}{$\begin{array}{c}\begin{array}{c}\text { Standardized } \\
\text { Coefficients }\end{array} \\
\text { Beta } \\
\end{array}$} & \multirow[b]{2}{*}{$\mathrm{t}$} & \multirow[b]{2}{*}{ Sig. } \\
\hline & $\mathrm{B}$ & Std. Error & & & \\
\hline $\begin{array}{ll}1 & \text { (Constant) } \\
& \text { Penempatan_X } \\
\end{array}$ & $\begin{array}{r}13,242 \\
, 696 \\
\end{array}$ & $\begin{array}{r}7,433 \\
, 174 \\
\end{array}$ &, 590 & $\begin{array}{l}1,782 \\
4,006 \\
\end{array}$ & $\begin{array}{l}, 085 \\
, 019 \\
\end{array}$ \\
\hline
\end{tabular}

a. Dependent Variable: Prestasi kerja_Y

Sumber : Output SPSS for Windows 22, 2015

Setelah diperoleh hasil perhitungan koefisien korelasi antara Penempatan pegawai terhadap Prestasi kerja maka dilakukan uji hipotesis dengan langkah-langkah pengujian berikut:

1. Menentukan Hipotesis

$\mathrm{H}_{0}$ : tidak ada pengaruh antara Penempatan pegawai terhadap Prestasi kerja
$\mathrm{H}_{\mathrm{a}}$ : ada pengaruh antara Penempatan pegawai terhadap Prestasi kerja

2. Menentukan tingkat signifikansi

Tingkat signifikansi mengunakan alpha 5\% (signifikansi 5\% atau 0,05 adalah ukuran standar yang sering digunakan dalam penelitian).

3. Menentukan $t_{t a b e l}$

Tabel distribusi $t$ dicari pada alpha $=$ $5 \%$ (uji 1 sisi) dengan derajat kebebasan (DF) n-k-1 atau 32-1-1= 
30 (n adalah jumlah kasus dan $\mathrm{k}$ adalah jumlah variabel independen). Hasil diperoleh untuk $t_{\text {tabal }}$ sebesar 2,042.

4. Apabila $t_{\text {hitung }}>t_{\text {tabel }}$ maka $H_{0}$ ditolak.

Artinya ada pengaruh yang signifikan antara Penempatan pegawai terhadap Prestasi kerja pegawai di Kantor Media Lintas Indonesia Kota Palembang

5. Apabila $t_{\text {hitung }}<t_{\text {tabal }}$ maka $\mathrm{H}_{\mathrm{a}}$ diterima artinya tidak ada pengaruh yang signifikan antara Penempatan pegawai terhadap Prestasi kerjapegawai di Kantor Media Lintas Indonesia Kota Palembang

6. Membandingkan $t_{\text {hitung }}$ dengan $t_{\text {tabel }}$ Nilai $\quad t_{\text {hitung }}>t_{\text {tabel }} \quad(4,006>2,042)$ maka $\mathrm{H}_{\mathrm{a}}$ ditolak dan $\mathrm{H}_{\mathrm{o}}$ diterima artinya ada pengaruh secara signifikan antara Penempatan pegawai terhadap Prestasi Kerja pegawai di Kantor Media Lintas Indonesia Kota Palembang.

\section{Gambar 1}

\section{Kurva Uji-t Pengaruh Penempatan Pegawai Terhadap Prestasi Kerja}

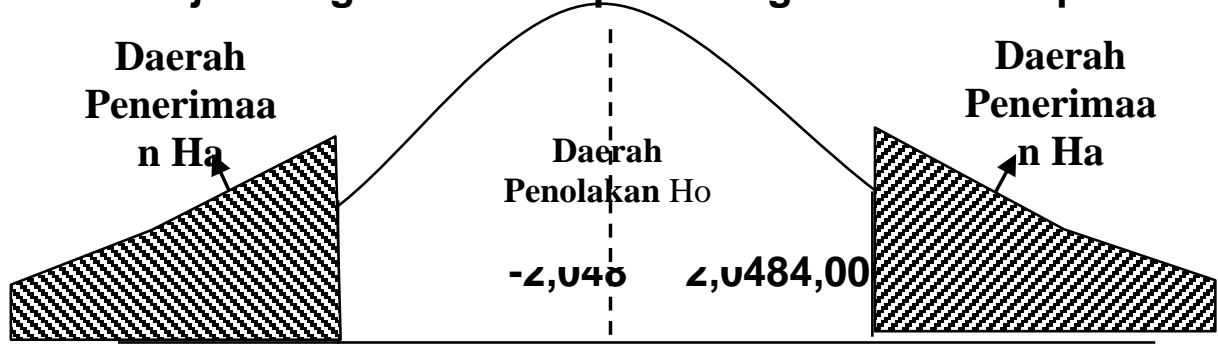

Gambar 2. Grafik Normal P-P Plot

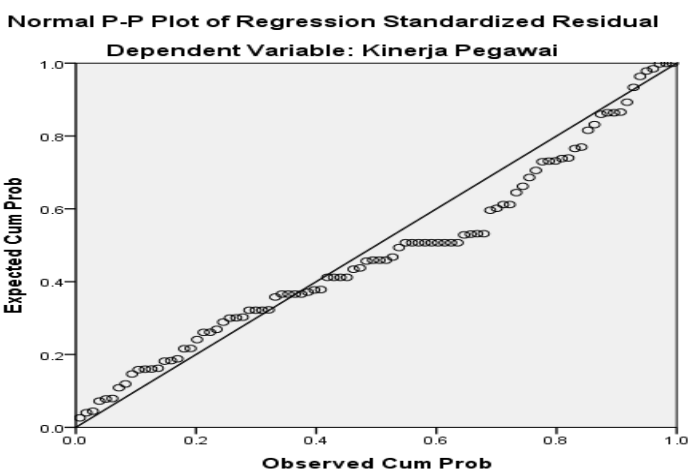

\section{H. PEMBAHASAN}

Dari hasil perhitungan Konstanta sebesar 13,242 artinya jika Penempatan pegawai $(X)$ nilainya adalah 0 , maka Prestasi kerja (Y) nilainya sebesar 13,242 Sedangkan koefisien regresi variabel Penempatan pegawai (X) sebesar 0,696 artinya jika Penempatan kerja mengalami kenaikan sebesar 1, maka Prestasi kerja (Y) akan mengalami peningkatan sebesar 0,696. Koefisien bernilai positif artinya ada pengaruh positif antara Penempatan pegawai dengan Prestasi kerja, semakin baik Penempatan pegawai yang di lakukan maka akan meningkatkan pula Prestasi kerja pada Kantor Media Lintas Indonesia Kota Palembang. 
Dari hasil perhitungan sebelumnya, di peroleh nilai korelasi ( $R$ ) adalah sebesar 0,590. Berdasarkan pedoman untuk memberikan interpretasi koefisien korelasi, maka dapat di simpulkan bahwa penempatan pegawai dan prestasi kerja sedang. Sedangkan arah hubungan antara kedua variabel tersebut adalah positif atau searah, artinya bila penempatan pegawai di laksanakan dengan baik maka prestasi kerja akan meningkat, begitu pula sebaliknya.

Koefisien determinasi data digunakan untuk mengetahui seberapa besar pengaruh atau distribusi Penempatan pegawai terhadap prestasi kerja. Dari hasil perhitungan sebelumnya, diperoleh koefisien determinasi ( $R$ Square) sebesar 34,9\%. Hal ini menunjukkan bahwa pengaruh Penempatan pegawai terhadap prestasi kerja sebesar 34,9\%, sedangkan sisanya $65,1 \%$ merupakan pengaruh dari faktor-faktor lain yang tidak diteliti dalam penelitian ini.

Pada tahap terakhir ini dilakukan pengujian hipotesis dengan menggunakan $u j i$ t dengan menggunakan taraf signifikansi 0,05 artinya bahwa hasil penelitian ini dapat dipertanggung jawabkan atau masih bisa diterima bila ada kekeliruan dalam proses penelitian tidak lebih dari 0,05.Sesuai dengan perhitungan sebelumnya, maka diperoleh thitung sebesar 4,006 dan tabel sebesar 2,042 sehingga dapat disimpulkan bahwa $\mathrm{Ha}_{\mathrm{a}}$ ditolak dan $\mathrm{H}_{\mathrm{o}}$ diterima karena $t_{\text {hitung }}>$ $t_{\text {tabel }}=4,006>2,042$ artinya bahwa Penempatan pegawai ada pengaruh secara signifikan terhadap prestasi kerja pada pegawai di Kantor Media Lintas Indonesia Kota Palembang.

Di sisi lain, para pegawai berkepentingan untuk pengembangan diri dan promosi pekerjaan, secara umum dapat dikatakan bahwa prestasi kerja pegawai yang baik bertujuan untuk menigkatkan produktivitas. Oleh karena itu, perbaikan sistem kerja dilakukan setiap komponen yang ada dalam organisasi. Tujuan-tujuan tersebut akan di butuhkan sistem manajemen kinerja pegawai yang baik.

Berdasarkan penjelasan di atas, maka dapat diambil kesimpulan bahwa Penempatan pegawaimerupakan suatu usaha atau upaya kegiatan suatu organisasi dengan standar yang telah di tetapkan, apakah sudah sesuai dengan rencana yang telah di tentukan, serta melakukan tindakan koreksi apabila terjadi penyimpangan yang terjadi pada organisasi.

\section{H. KESIMPULAN DAN SARAN}

1) Kesimpulan

Berdasarkan analisis data yang telah dilakukan dan pembahasan yang diperoleh, maka dapat disimpulkan:

a) Persamaan regresi linier sederhana $Y=13,242+0,696 \mathrm{X}$ menunjukan Konstanta sebesar 13,242 Penempatan pegawai (X) nilainya adalah 0, maka Prestasi kerja (Y) nilainya sebesar 13,242. Sedangkan koefisien regresi variabel Penempatan pegawai $(X)$ sebesar 0,696 artinya jika Prestasi kerja mengalami naik 1, maka Prestasi kerja (Y) akan mengalami peningkatan sebesar 0,696.

b) Berdasarkan perhitungan menggunakan koefisien korelasi (R) diperoleh nilai sebesar 0,590maka karena hasil yang didapat merupakan angka positif, hal ini berarti hubungan yang sedang antara Penempatan pegawai terhadap Prestasi kerja.

c) Dari hasil perhitungan koefisien determinasi diperoleh nilai $\mathrm{R}$ Square $=$ 0,349 . Hal ini berarti variabel Prestasi 
kerja dipengaruhi oleh Variabel Penempatan pegawai sebesar 34,9\%, sedangkan sisanya $65,1 \% \%$ dipengaruhi oleh variabel lain yang tidak diteliti.

d) Ada pengaruh positif dan signifikan antara penempatan pegawai terhadap prestasi kerja pegawai di Kantor Media Lintas Indonesia Kota Palembang. Hal ini berdasarkan hasil pengujian hipotesis yang diperoleh dimana nilai $t_{\text {hitung }}$ lebih besar dari nilai $t_{\text {tabel }}(4,006>2,042)$ maka keputusannya adalah menolak hipotesis nol $\left(\mathrm{H}_{\mathrm{a}}\right)$ dan menerima hipotesis alternative $\left(\mathrm{H}_{\mathrm{o}}\right)$.

\section{Saran}

Berdasarkan hasil analisa dan pembahasan, beberapa saran yang disampaikan dalam penelitian ini adalah:

a) Penempatan pegawai yang ada selama ini baik dapat dipertahankan dan terus ditingkatkan supaya memberikan prestasi kerja yang lebih baik juga.

b) Apabila organisasi meletakan Penempatan pegawai yang tepat dan sesuai maka Prestasi kerja akan memberikan hasil yang lebih baik.

c) Organisasi perlu memberikan pendidikan dan pelatihan bagi pegawai agar pegawai dapat meningkatkan prestasi kerjanya.

d) Walaupun dalam penelitian ini penempatan pegawai berpengaruh sedang terhadap prestasi kerja, tapi organisasi perlu memberikan tanggung jawab atas pekerjaanya.

\section{DAFTAR PUSTAKA}

Handoko, T hani. 2001. Manajemen Personalia dan Sumber Daya
Manusia. Yogyakarta. BPFEYogyakarta.

Hanggraeni, Dewi, 2012, Manajemen Sumber Daya Manusia. Cetakan Pertama UI, Jakarta.

Hasibuan, Melayu SP, 2013, Manajemen Sumber Daya Manusia. Bumi Aksara. Jakarta.

Priyato, Dwi. 2013. Paham Analisis Statistik Data dengan SPSS. Yogyakarta. Mediakom.

Ridwan. 2009. Metode \& Teknik Menyusun Proposal Penelitian. Alfabeta: Jakarta.

Siagian, Sondang P. 2013. Manajemen Sumber Daya Manusia. Jakarta. Bumi Aksara.

Sedarmayani, 2011, Manajemen Sumber Daya Manusia. Cetakan kelima, Refika Aditama, Bandung.

Sugiyono. 2013. Metode Penelitian Manajemen. Bandung. Alfabeta.

Sujarweni, V Wiratna, 2014, SPSS Untuk Penelitian, Cetakan Pertama, Pustaka Baru Press, Yogyakarta.

Sutrisno, Edi. 2012. Manajemen Sumber Daya Manusia. Jakarta. Kencana Prenada Media Group.

Rivai, Veithzal \& Mulyadi Dedy, 2010, Kepemimpinan Dan Prilaku Organisasi, Cetakan kedelapan, Rajawali Perc, Jakarta. 